\title{
Letters
}

\section{COUGARS IN}

THE RASPBERR Y PATCH?
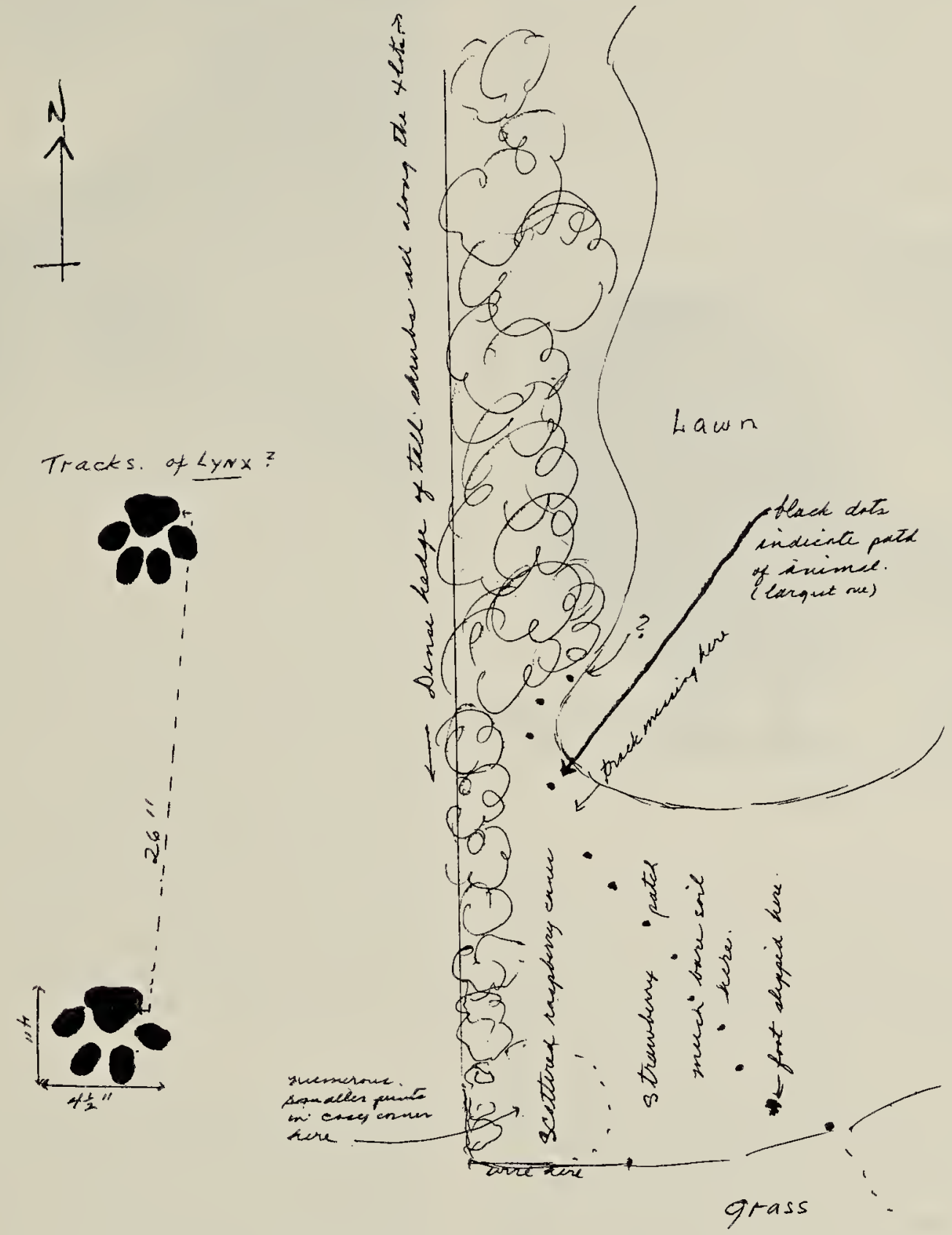

While transplanting a few raspberry canes this afternoon I discovered 1? large cat tracks along with numerous smaller ones. All tracks were distinctly imprinted in the wet soil. The large tracks measured $41 / 2 " \mathrm{x} 4$ ". The two sets of smaller tracks were 3 " $\times 3$ " and $21 / 2 "$ x $21 / 2 "$. I believe these tracks to be those of a lynx and two kittens. (I have enclosed a sketch of the form of the tracks).

It would appear that the family travelled over the lawn in the shadow of a dense hedge of tall shrubs before stepping into the garden area. All tracks were visible on lot No. 4, block 27, in the town of Carlyle - $(300$ block, 7th Street West).

Just thought some one of the Blue Jay readers might be interested. Doris Silcox, Box 549, Carlyle, Saskatchewan. SOC ORO.

Editor's Note: For additional reports of cougars in the Moose Mountain-Antler area see "Cougar Kittens" by Tom White in the March, 1973, Blue Jay (31:42-43). 


\section{ANOTHER TON OF SUNFLOWER SEEDS}

Again this winter, we hauled a ton of sunflower seeds from southern Manitoba to supply 6 bird feeders near Togo (see W.J.C. May, Blue Jay 32: 181, Sept. 1974). A columnist in the Brandon Sun suggested such mileage was likely unnecessary - but failed to locate a nearer supply!

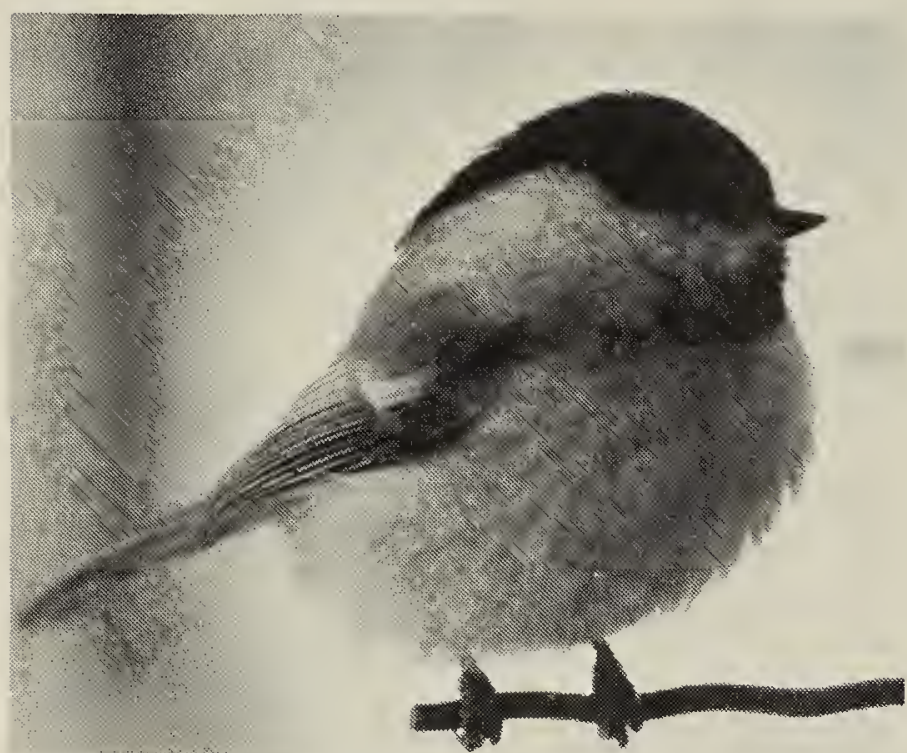

Black-capped Chickadee.

Lorne Scott

A new window-sill tray, laden with sunflower seeds and augmented by rapeseed screenings, allowed us to observe closely 8 chickadees, 2 Hairy Woodpeckers, over 100 Common Redpolls and 2 Hoary Redpolls. We also had 23 Pine Grosbeaks, which are tamer and more musical than the Evenings, but they departed early in March. The Evening Grosbeaks came earliest in the winter and at the time of writing (March 12) have invaded us in unbelievable numbers. - Wanda May, Togo, Sask.

\section{WINTER BIRDS AT ITUNA}

I have had a lot of pleasure from my bird feeder this past winter, and thought others might be interested.

It began last November, when a flock of Evening Grosbeaks flew in, and about three dozen stayed around for nearly 3 weeks, gradually dwindling in numbers towards the end. I didn't see them again till the end of

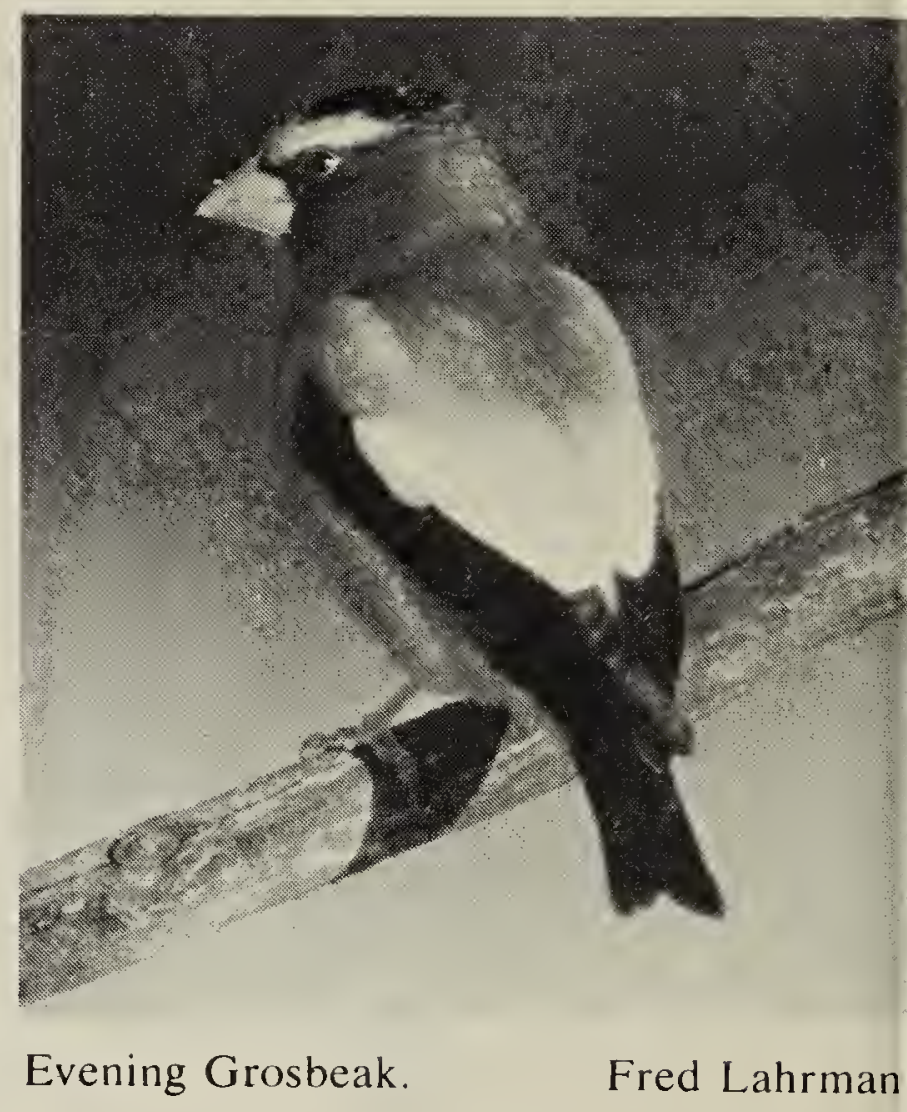

March, when a small flock (about a dozen) came back to the feeder, which I kept supplied with sunflower seed. Some of these are still around at the time of writing, (April 28).

The day after the snowstorm that we had on April 16th a little flock of Purple Finches hung around, and I had the most unusual sight of 9 Evening Grosbeaks on the feeder, and several Purple Finches on the ground below, surely a delightful experience. That same morning there were 2 or 3 very sad and dispirited Robins around so I put out quite a large tray of feed and by afternoon there were no less than 24 Robins busy around it, incidentally, in a much more cheerful mood.

In addition to these a very few chickadees and a Downy Woodpecker were regular visitors all winter long to a suet feeder. - Mary T. Brennan, Ituna, Saskatchewan. SOA 1 NO.

\section{MARCH BIRDS AT ITUNA, SASKATCHEWAN}

The Junior Sportsmen of the Ituna $4 \mathrm{H}$ Club, went for a drive in search of spring birds. We sighted 12 species. They are Chickadees, Downy Woodpecker, Grouse, Magpies, Redpolls, 
Blackbirds, Evening Grosbeaks, Meadowlarks, Bluebirds, Hungarian Partridge, Sharp-tailed Grouse, and Robins. We enjoyed the trip very much, which was on 29th of March nd it lasted 1 hour and it was a 20nile trip. David Brennan, Age 12, Box 04, Ituna, 4H Club.

\section{FROLICKING MAGPIES}

Am wondering if any of you have ad a similar experience to the one I had this morning, i.e., family of eight nagpies seemingly playing or teasing a woodchuck. I really believe they were hlaying and having fun. For they did hot peck but merely hopped over and ibout him. They especially stared him $n$ the face like a fighting cock and blocked his retreat to his shelter under he slab pile. The woodchuck did not eem overly concerned for he coninued to feed, but now and then he made a rush at his tormentors. The click of my camera put the birds to fight.

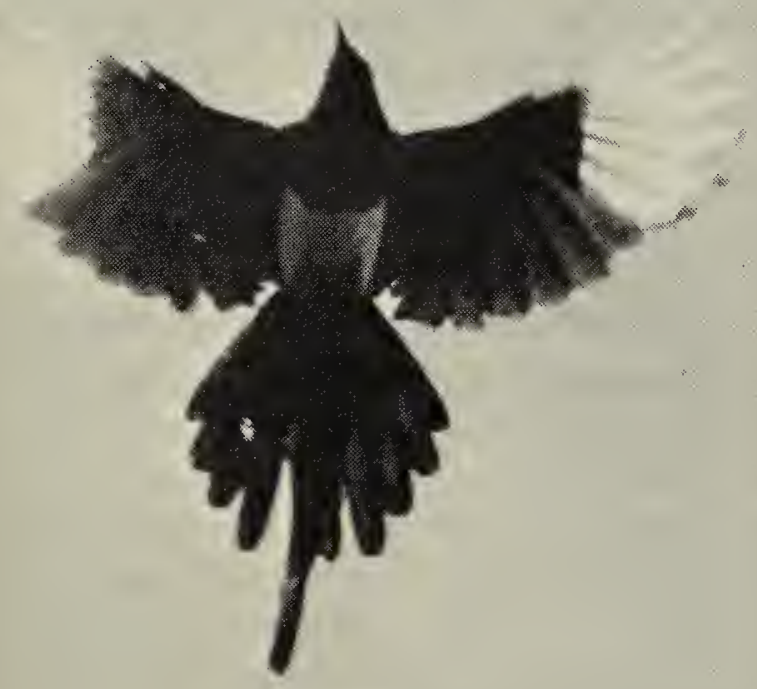

Magpie.

Gary Anweiler
It is possible that this behavior is similar to that of a kitten playing with its prey and a forerunner to killing it. It's a shame their methods of livelihood and survival are so cruel, for they are so pretty and graceful, and, seemingly, very intelligent.

You notice I referred to this woodchuck as "he" which is correct, for he is one of a pair that I encourage to inhabit my yard each year, mainly for my interest. They also help keep the weeds and, especially, dandelions clipped. They usually bring forth a batch of kits, as many as six, but none this year. - Harold E. Hobden, Box 171, Worsley, Alberta. TOH 3 WO

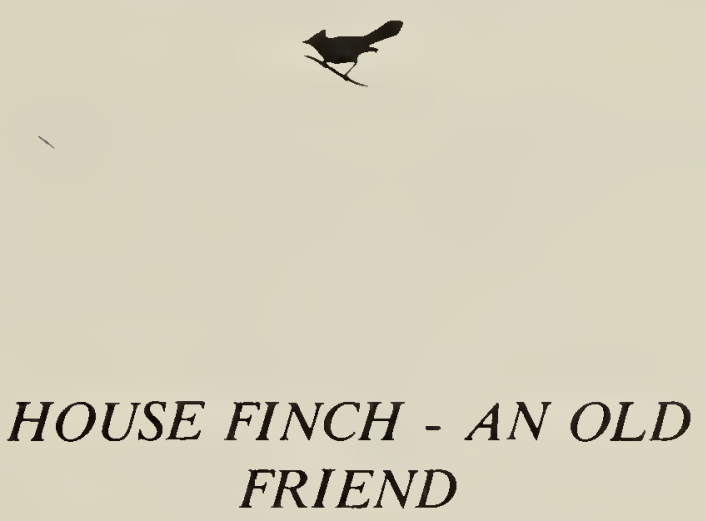

Most of us enjoy meeting old friends, and for this reason February 6, 1976, was a very exciting day for me. As I worked in the kitchen by my "bird-watching" window, I raised my eyes for the umpteenth time and was rewarded by the sight of two bright beady eyes staring at me from a distance of 5 or 6 feet. This little beauty sitting on our electric wires was a species which I had come to know very well indeed, in my home town of Vancouver, B.C. I had the pleasure of renewing acquaintance with hundreds of his friends and relatives in August, 1975, when I spent two weeks in Vancouver, sprawled on my brother's sun deck at eye level with the feeders. My little friend was a House Finch in full colour and never before reported in the Saskatoon area. He sat on the wires just above eye level until I had memorized every single marking on his underside, then he obligingly dropped down a couple feet to a clothes line, where all his upper parts were in perfect position for viewing. Binocs were completely superfluous as we 
were so close to one another. There was no doubt whatsoever that I was being visited by a male House Finch a bird almost as large as a House Sparrow but sleeker. The male is brownish with strong narrow stripes on the flanks and belly. He resembles a Purple Finch, of which there have been many in our yard. This specimen seemed to be in perfect condition and so brilliantly coloured. How he arrived in our part of the country particularly at this time of year is a mystery but he seemed happy and content with his lot in life. I sincerely hope he made it through the rest of the winter. - Pat O'Neil, 1125 Elliott Street, Saskatoon, Sask. S7N 0V4.

Editor's Note: The following excerpt is from Breeding Bird Survey Newsletter Number 4 (April 20, 1976): "The most spectacular changes continue to be the increase in the House Finch east of the Mississippi River (mean annual increase of $30 \%)$. . .

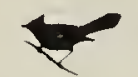

\section{PROBABLE MELANISTIC WREN AT KATEPWA}

While in Katepwa at Salter's Beach in early August, 1975 my brother Eric and I observed a completely dark wren singing madly in the dense brush by the lake. We were obviously near the nest, for it was frantic in its attempts to distract us, and its song was more of an incessant babble to distract or drive us away than anything else.

Since the different species of wrens do not adhere to strict areas in which they sing, that aspect did not help in identification; although one bush that was approached always brought forth the wren to drive us away. My brother observed a normal wren, its mate, seen with it. This wren did not have the plumage of either species of marsh wren but was more like a House or Winter Wren. Eric indicates that it seemed smaller, slightly darker and had a shorter tail than the House
Wren, like a Winter Wren, which is not likely because their occurrence in Saskatchewan is not common. - Tony Lang, 65 Bobolink Bay, Regina, Sask

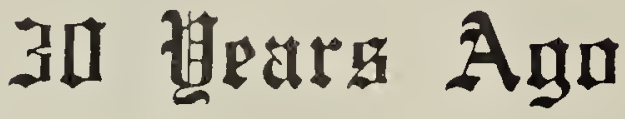

The following excerpts are from the 16-page mimeographed Blue Jay of April-June, 1946, the last issue Mrs. Priestly edited before her death.

"An effort is being made to have April 10, the late Jack Miner's birthday, set aside as National Bird Day ...". A questionnaire about the status of the Red Lily revealed that the flower was decreasing in most of the 200 communities replying. In 13 it had been extirpated and in 17 it was increasing . . . There were notes by L. T. McKim, Ralph Stueck and Steve Mann on ground squirrels and a jumping mouse hibernating in straw stacks ..

Stuart Houston had an article about J. H. Wilson of Indian Head who had banded 6,927 birds of 23 species. mostly ducks. A Marbled Godwit, banded at Yorkton, was found dead near Los Angeles. A Blue-winged Teal, also banded at Yorkton, was shot the next day 563 miles away in Minnesota ... J. D. Ritchie wrote about a wasp that had caught and carried 11 flies to its subterranean nest ... Maurice G. Street sent in the following: "A Canada Jay's nest found half completed March 18; this is rather later than the average. While hunting for other Canada Jay nests in a spruce bluff yesterday (24th), David Wright and I saw a pair of Black-capped Chickadees take a bath, almost at our feet, in a little pool of water which had formed at the base of a stump. The temperature was only just above freezing. Later we saw them catching tiny moths that were flying in somc numbers." The last three pages wert devoted to information on Whooping Cranes and a request that any sightings be sent to Fred Bard. 